\title{
Effect of DR1558, a Deinococcus radiodurans response regulator, on the production of GABA in the recombinant Escherichia coli under low $\mathrm{pH}$ conditions
}

\author{
Sung-ho Park' , Yu Jung Sohn ${ }^{2}$, Si Jae Park ${ }^{2^{*}}$ and Jong-il Choi ${ }^{\text {* }^{*}}$
}

\begin{abstract}
Background: Gamma aminobutyric acid (GABA) is an important platform chemical, which has been used as a food additive and drug. Additionally, GABA is a precursor of 2-pyrrolidone, which is used in nylon synthesis. GABA is usually synthesized from glutamate in a reaction catalyzed by glutamate decarboxylase (GAD). Currently, there are several reports on GABA production from monosodium glutamate (MSG) or glucose using engineered microbes. However, the optimal pH for GAD activity is 4, which is the limiting factor for the efficient microbial fermentative production of GABA as fermentations are performed at pH 7. Recently, DR1558, a response regulator in the two-component signal transduction system was identified in Deinococcus radiodurans. DR1558 is reported to confer cellular robustness to cells by binding the promoter regions of genes via DNA-binding domains or by binding to the effector molecules, which enable the microorganisms to survive in various environmental stress conditions, such as oxidative stress, high osmotic shock, and low pH.
\end{abstract}

Results: In this study, the effect of DR1558 in enhancing GABA production was examined using two different strategies: whole-cell bioconversion of GABA from MSG and direct fermentative production of GABA from glucose under acidic culture conditions. In the whole-cell bioconversion, GABA produced by E. coli expressing GadBC and DR1558 $\left(6.52 \mathrm{~g} / \mathrm{L} \mathrm{GABA}\right.$ from $\left.13 \mathrm{~g} / \mathrm{L} \mathrm{MSG} \cdot \mathrm{H}_{2} \mathrm{O}\right)$ in shake flask culture at pH 4.5 was 2.2-fold higher than that by E. coli expressing only $\mathrm{GadBC}\left(2.97 \mathrm{~g} / \mathrm{L}\right.$ of GABA from $\left.13 \mathrm{~g} / \mathrm{L} \mathrm{MSG} \cdot \mathrm{H}_{2} \mathrm{O}\right)$. In direct fermentative production of GABA from glucose, E. coli $\triangle g a b T$ expressing isocitrate dehydrogenase (IcdA), glutamate dehydrogenase (GdhA), GadBC, and DR1558 produced 1.7-fold higher GABA (2.8 g/L of GABA from $30 \mathrm{~g} / \mathrm{L}$ glucose) than E. coli $\triangle$ gabT expressing IcdA, GdhA, and GadBC (1.6 g/L of GABA from $30 \mathrm{~g} / \mathrm{L}$ glucose) in shake flask culture at an initial pH 7.0. The transcriptional analysis of $E$. coli revealed that DR1558 conferred acid resistance to $E$. coli during GABA production. The fed-batch fermentation of E. coli expressing IcdA, GdhA, GadBC, and DR1558 performed at pH 5.0 resulted in the final GABA titer of $6.16 \mathrm{~g} / \mathrm{L}$ by consuming $116.82 \mathrm{~g} / \mathrm{L}$ of glucose in $38 \mathrm{~h}$.

Conclusion: This is the first report to demonstrate GABA production by acidic fermentation and to provide an engineering strategy for conferring acid resistance to the recombinant $E$. coli for GABA production.

\footnotetext{
*Correspondence: parksj93@ewha.ac.kr; choiji01@jnu.ac.kr

1 Department of Biotechnology and Bioengineering, Interdisciplinary

Program for Bioenergy \& Biomaterials, Chonnam National University, 77 Yongbong-ro, Gwangju 61186, Republic of Korea

2 Division of Chemical Engineering and Materials Science, Ewha Womans University, 52 Ewhayeodae-gil, Seodaemun-gu, Seoul 03760, Republic of Korea
}

c) The Author(s) 2020. This article is licensed under a Creative Commons Attribution 4.0 International License, which permits use, sharing, adaptation, distribution and reproduction in any medium or format, as long as you give appropriate credit to the original author(s) and the source, provide a link to the Creative Commons licence, and indicate if changes were made. The images or other third party material in this article are included in the article's Creative Commons licence, unless indicated otherwise in a credit line to the material. If material is not included in the article's Creative Commons licence and your intended use is not permitted by statutory regulation or exceeds the permitted use, you will need to obtain permission directly from the copyright holder. To view a copy of this licence, visit http://creativeco mmons.org/licenses/by/4.0/. The Creative Commons Public Domain Dedication waiver (http://creativecommons.org/publicdomain/ zero/1.0/) applies to the data made available in this article, unless otherwise stated in a credit line to the data. 
Keywords: Gamma aminobutyrate, DR1558, Acid resistance, Deinococcus radiodurans, Escherichia coli

\section{Background}

Conventional petroleum-based methods for the production of valuable chemicals are associated with several challenges, such as environmental concerns and limited availability of fossil fuel. Hence, various bio-based production methods using renewable feedstocks have recently been developed $[1,2]$. To address the growing demand for the production of value-added products, such as platform chemicals and biopolymers from renewable resources, several engineered microorganisms have been developed [3-9].

Gamma aminobutyric acid (GABA), a non-protein amino acid, is widely expressed in prokaryotic and eukaryotic organisms [10]. GABA is the primary inhibitory neurotransmitter in the nervous system of mammals. Generally, GABA is used in pharmaceuticals or food additives for its physiological functions [11-14]. Additionally, GABA has applications in the bio-based chemical and polymer industries, where GABA is used as the precursor of 2-pyrrolidone, which can be used as a solvent or as a monomer for the synthesis of nylon $4[15$, $16]$.

Several studies have reported the microbial production of GABA through proton-consuming decarboxylation of L-glutamate using two biological processes: whole-cell bioconversion or direct fermentation. GABA is mainly produced through whole-cell bioconversion of MSG or L-glutamate to GABA by heterologous expression of glutamate decarboxylase (GAD) in the host strain [15, 17-24]. Additionally, several metabolically engineered microorganisms, such as Corynebacterium glutamicum and Escherichia coli have been developed for the direct fermentative production of GABA from renewable resources, such as glucose and xylose [25-31]. However, there are still several limitations associated with the efficient microbial fermentative production of GABA. For example, the optimal $\mathrm{pH}$ for GAD activity is around 4.5, though generally fermentation process of various industrial microorganisms such as E. coli, C. glutamicum, and Lactobacillus is performed around $\mathrm{pH}$ 7. These limitations could be addressed by developing GAD able to efficiently convert glutamate into GABA at $\mathrm{pH} 7$ or by developing host strains that supports the enhanced cell robustness under acidic stress for facilitation of the GAD activity. In this regards, the recombinant C. glutamicum strain expressing GAD that is active at a wide $\mathrm{pH}$ range was reported to produce $38.6 \mathrm{~g} / \mathrm{L}$ GABA in $72 \mathrm{~h}$ fedbatch fermentation from glucose [32]. However, other strategy such as increasing cell tolerance to acidic stress for acidic fermentative production of GABA is but not yet developed.

Deinococcus radiodurans is reported to be resistant to various abiotic stress factors, such as $\gamma$-radiation, oxidizing agents, and desiccation [33]. Recently, DR1558, a response regulator in the two-component signal transduction system, was identified in $D$. radiodurans. The expression of DR1558, which exhibits a recA-like expression pattern, was reported to be enhanced (approximately 5.64-fold) in response to $15 \mathrm{kGy}$ of gamma radiation [34]. DR1558 is reported to induce alterations in the cell by directly binding to the promoter regions of genes via DNA-binding domains or by binding to the effector molecules in response to environmental stress. One study has employed DR1558 for increasing the tolerance of $E$. coli against low $\mathrm{pH}$, heat, and salt stresses [35]. Additionally, DR1558 has been used to enhance cell robustness and production of succinate, 2,3-butanediol (2,3-BDO) and poly(3-hydroxybutyrate) $[\mathrm{P}(3 \mathrm{HB})]$ in the recombinant $E$. coli strains [36-38].

In this study, the effect of $D$. radiodurans DR1558 on GABA production was examined in the recombinant $E$. coli strains under low $\mathrm{pH}$ culture conditions using two different strategies: whole-cell bioconversion of MSG to GABA and direct fermentative production of GABA from glucose. The quantitative real-time polymerase chain reaction (qRT-PCR) analysis was performed to evaluate the expression level of genes related to central metabolism and acid resistance (AR) under acidic challenge in the $d r 1558$-overexpressing E. coli strains. Furthermore, fed-batch fermentation was carried out for direct fermentative production of GABA from glucose as a proof-of-concept and demonstrated that DR1558 can be robustly used in the fermentation scale.

\section{Results and discussion}

Examination of DR1558 expression for the acid-resistant conversion of MSG into GABA at low $\mathrm{pH}$

The optimal $\mathrm{pH}$ for GAD, which catalyzes the conversion of glutamate into GABA, is around 4.5. This $\mathrm{pH}$ is lower than the neutral $\mathrm{pH}$ generally used for cell cultivation [39, 40]. Thus, we hypothesized that enhancing $E$. coli resistance to low $\mathrm{pH}$ may have a positive effect on GABA production as GABA can be produced at the $\mathrm{pH}$ optimum for the decarboxylation activity of GAD. To investigate the effect of DR1558 on GABA production, the recombinant E. coli WGB100 strain expressing GadBC and DR1558 and $E$. coli BL21(DE3) strain expressing only GadBC were cultured in the MR medium ( $\mathrm{pH} 7.0$ ) supplemented with 
$20 \mathrm{~g} / \mathrm{L}$ glucose and $5 \mathrm{~g} / \mathrm{L}$ yeast extract. When the optical density at $600 \mathrm{~nm}\left(\mathrm{OD}_{600}\right)$ of the culture reached 1.0, isopropyl- $\beta$-thiogalactoside (IPTG; final concentration, $0.5 \mathrm{mM}$ ) was added to the culture medium to induce protein expression. The cells were cultured for $8 \mathrm{~h}$ and transferred to the MR medium ( $\mathrm{pH}$ 4.5) supplemented with $20 \mathrm{~g} / \mathrm{L}$ glucose, $5 \mathrm{~g} / \mathrm{L}$ yeast extract, and $13 \mathrm{~g} / \mathrm{L}$ MSG $\cdot \mathrm{H}_{2} \mathrm{O}$. The $E$. coli BL21(DE3) strain expressing only GadBC exhibited a low conversion yield (41\%; conversion of $13 \mathrm{~g} / \mathrm{L}$ MSG. $\mathrm{H}_{2} \mathrm{O}$ into $2.97 \mathrm{~g} / \mathrm{L} \mathrm{GABA}$ ) (Fig. 1b). However, the E. coli WGB100 strain expressing GadBC and DR1558 exhibited a high GABA yield (87.3\%; conversion of $13 \mathrm{~g} / \mathrm{L}$ MSG $\cdot \mathrm{H}_{2} \mathrm{O}$ into $6.31 \mathrm{~g} / \mathrm{L}$ GABA) within $24 \mathrm{~h}$. Incubating the $E$. coli WGB100 strain till $60 \mathrm{~h}$ resulted in the production of $6.52 \mathrm{~g} / \mathrm{L}$ GABA corresponding to a $90 \%$ yield (Fig. 1a). In previous report, the productivity of $0.12 \mathrm{~g} \mathrm{GABA} / \mathrm{L} / \mathrm{h}$ was obtained by recombinant $E$. coli equipped with the C-terminus synthetic complex of GadB and GadC (pH3BN) [41]. Additional expression of DR1558 along with the C-terminus synthetic complex of GadB and GadC in the engineered E. coli WGB100 in this study allowed the increased productivity of $0.26 \mathrm{~g}$ GABA/L/h [41].

\section{Transcriptional analysis of genes involved in central} metabolism and glutamate acid-dependent acid resistance (GDAR) system in E. coli

The qRT-PCR analysis was performed to analyze the expression patterns of 37 genes associated with the central carbon metabolism, AR system, and respiratory chain complexes in the E. coli WGB100 and control strains as summarized in Fig. 2 and Additional file 1: Table S2.

When the $\mathrm{pH}$ was decreased, the expression levels of genes involved in the central metabolic pathways, such as glycolysis and tricarboxylic acid (TCA) cycle in the $E$. coli WGB100 strain were upregulated when compared to those in the control strain (Additional file 1: Table S2). The expression levels of $p t s G$ and $p y k A$, which are associated with the glycolytic pathway, in the $E$. coli WGB100 strain were upregulated by 2.1-, and 1.76fold, respectively, when compared to the control strain. This indicated enhanced glucose uptake by the E. coli WGB100 strain. As shown in Fig. 1, although the production of acetate in the recombinant $E$. coli WGB100 strain expressing both GadBC and DR1558 was similar to that of the control strain, the glucose consumption increased by 1.51 -fold. This suggested that the carbon flux towards acetate metabolism in the E. coli WGB100 strain decreased based on the production of acetate relative to the consumption of carbon source. The expression of the pox $B$ gene, which is involved in acetate metabolism, was downregulated by 3.67 -fold in the E. coli WGB100 strain when compared to its expression in the control strain (Additional file 1: Table S2). The downregulation of acetate metabolism was also observed in our previous study in the $d r 1558$-overexpressing $E$. coli for the production of 2,3-BDO and $\mathrm{P}(3 \mathrm{HB})[37,38]$.

Under low $\mathrm{pH}$ conditions, $E$. coli can maintain the $\mathrm{pH}$ homeostasis of the intracellular environment via carboxylation of amino acid by the proton-consuming AR system [42, 43]. E. coli contains four different amino
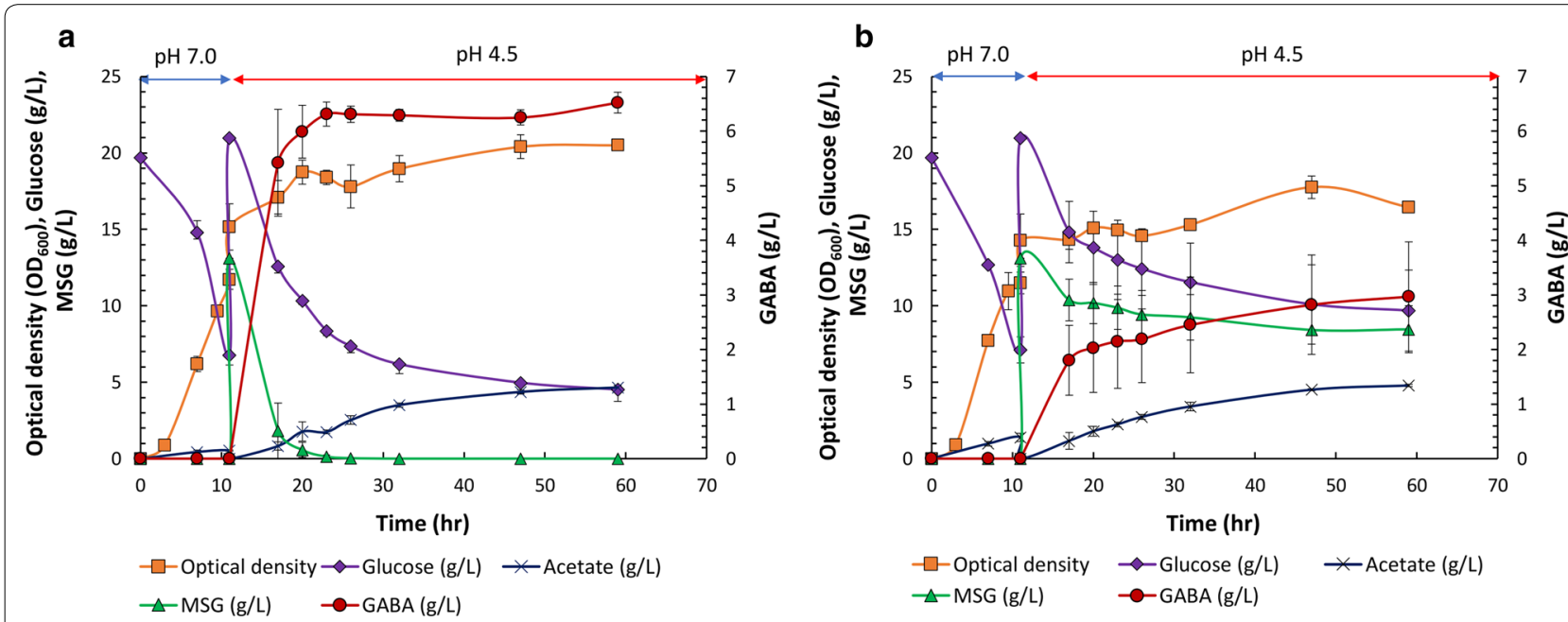

Fig. 1 Time profile of growth and production of gamma aminobutyric acid (GABA), monosodium glutamate (MSG), and metabolites in the whole-cell reaction by $\mathbf{a}$ Escherichia coli WGB100 strain expressing GadBC and DR1558 and b E. coli BL21(DE3) expressing only GadBC. The strains were cultivated in $50 \mathrm{~mL}$ MR medium supplemented with $5 \mathrm{~g} / \mathrm{L}$ yeast extract, $20 \mathrm{~g} / \mathrm{L}$ glucose, and $13 \mathrm{~g} / \mathrm{L} \mathrm{MSG} \cdot \mathrm{H}_{2} \mathrm{O}$ in a baffled flask at $30^{\circ} \mathrm{C}$. The data are represented as mean \pm standard deviation from three independent experiments 

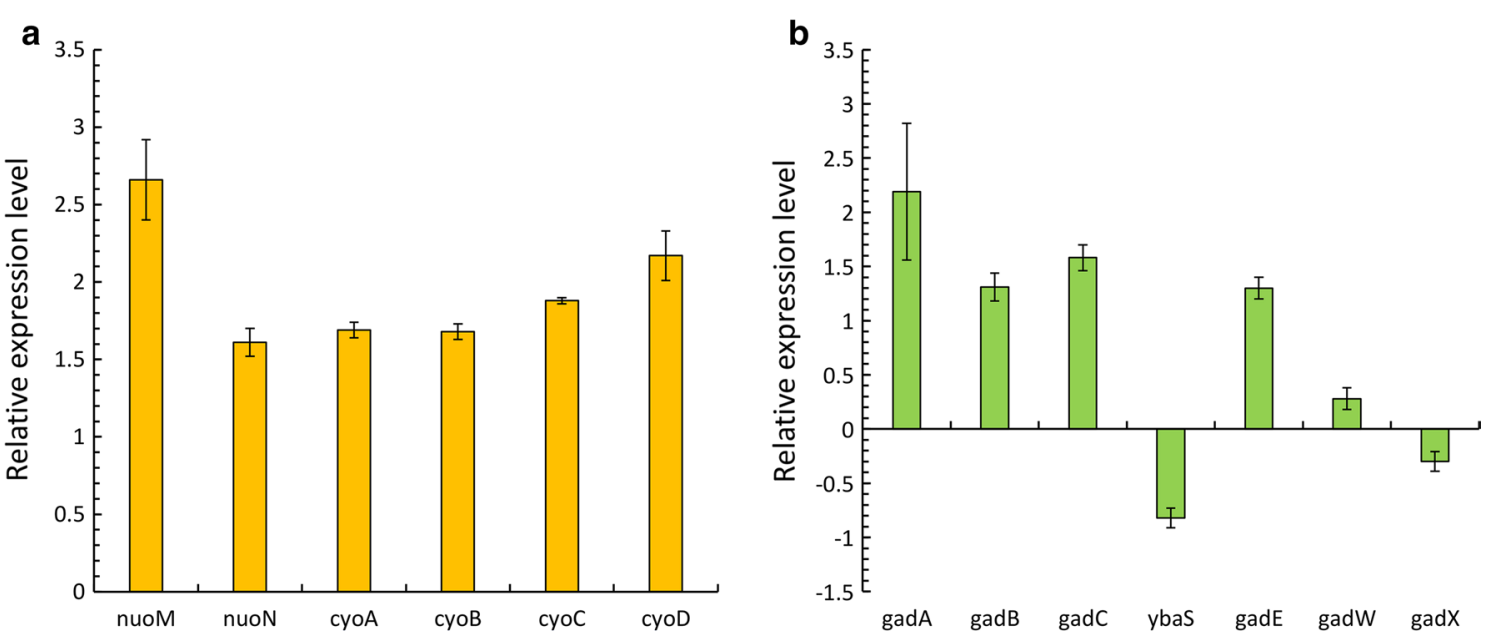

Fig. 2 Relative expression of genes related to acid resistance under mild acid stress conditions in dr1558-overexpressing Escherichia coli. a Glutamate-dependent acid resistance (GDAR) system; $\mathbf{b}$ components of the respiratory chain complexes. Each expression level was converted to the log base 2 of the value. For all genes represented in this figure, the $P$-value was $<0.05$ except for ybaS, gadW, and gadX. Histogram shows the mean of three biological replicates and error bars represent standard deviation

acid-dependent AR systems: GDAR, arginine-dependent acid resistance system (ADAR), lysine-dependent acid resistance system (LDAR), and ornithine-dependent acid resistance system (ODAR). Among these four systems, the GDAR system comprising GadA, GadB, and GadC is associated with low $\mathrm{pH}$ tolerance in the dr1558-overexpressing E. coli [35, 44-48]. Hence, the expression pattern of genes involved in the GDAR system was examined. The expression levels of $\operatorname{gad} A, \operatorname{gadB}$, and $\operatorname{gadC}$ genes in the E. coli WGB100 strain were upregulated by 2.19-, 1.13-, and 1.58-fold when compared to those in the control strain, respectively (Fig. 2b). Moreover, the mRNA levels of the rpoS and gadE genes, which indirectly affect the GDAR system, were also examined (Additional file 1: Table S2 and Fig. 2b). The proteins encoded by these genes, especially GadE, are involved in transcriptional regulation. GadE is the main regulator of the GDAR system and other acid fitness islands (AFIs), while RpoS is a sigma factor that simulates GadE expression $[49,50]$. The transcriptional analysis revealed upregulated expression levels of rpoS and gadE genes, which subsequently increased the expression level of GDAR system.

Along with the GDAR system, various respiratory chain complexes, such as cytochrome $b_{0}$ oxidase (Cyo), succinate dehydrogenase (SDH), and NADH dehydrogenase I (Nuo) that pump protons out of the cell are activated in E. coli as a metabolic response to acidic stress [43]. Cyo exports cytoplasmic protons by converting molecular oxygen to $\mathrm{H}_{2} \mathrm{O}$ to generate the proton motive force (PMF) during aerobic growth under acidic conditions. Additionally, Nuo catalyzes the oxidation of NADH to NAD, which contributes to PMF by directly pumping out the protons $[47,51]$. Hence, we also examined the expression level of genes associated with respiratory chain complexes. The expression levels of nuoMN and cyoABCD in the $d r 1558$-overexpressing strain were 1.5-fold higher than those in the control strain (Fig. 2a). Thus, overexpression of DR1558 resulted in enhanced expression of GDAR system as well as the respiratory chain complexes, which improved cell viability of $E$. coli WGB100 by conferring acid resistance during the conversion of MSG to GABA at low $\mathrm{pH}$ culture conditions.

\section{Reconstruction of GABA production pathway for the direct production of GABA from glucose}

The E. coli WGB100 strain can convert MSG into GABA while consuming glucose at $\mathrm{pH} 4.5$. Hence, we hypothesized that GABA could be produced directly from glucose at low $\mathrm{pH}$ culture conditions via production of glutamate, a direct precursor of GABA (Fig. 1). Therefore, we constructed the metabolic pathway for direct synthesis of GABA from glucose. In a previous study, enhanced expression of $i c d A$ encoding isocitrate dehydrogenase and $g d h A$ encoding glutamate dehydrogenase was reported to enhance the production of L-glutamate in the engineered E. coli [52]. Thus, the two E. coli BL21(DE3)-derived mutant strains, E. coli DGB201 (BL21(DE3) $\triangle g a b T$ expressing GdhA and, GadBC) and E. coli DGB202 (BL21(DE3) $\Delta g a b T$ expressing IcdA, GdhA and, GadBC), were investigated for the production of GABA from glucose (Table 1). The initial $\mathrm{pH}$ in the culture medium was set to 7.0 and the $\mathrm{pH}$ was not adjusted during the cultivation. After the formation of various organic acids, such as acetate and lactate, 
Table 1 Plasmid, strain used in this study

\begin{tabular}{|c|c|c|c|}
\hline Plasmids, strains & Characteristics & Origin $/ \mathrm{Ab}^{\mathrm{R}}$ & Source \\
\hline \multicolumn{4}{|l|}{ Plasmid } \\
\hline pACYCDuet-1 & $\mathrm{P}_{\mathrm{T} 7: \mathrm{MSC}}$ & $\mathrm{p} 15 \mathrm{~A} / \mathrm{Cm}^{\mathrm{R}}$ & Novagen \\
\hline $\mathrm{pH} 3 \mathrm{BN}$ & 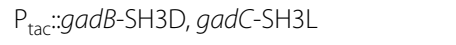 & ColE1/Amp ${ }^{R}$ & {$[41]$} \\
\hline pGB100 & $P_{T 7}:: d r 1558$ & $\mathrm{p} 15 \mathrm{~A} / \mathrm{Cm}^{\mathrm{R}}$ & This study \\
\hline pGB101 & $\mathrm{P}_{\mathrm{T} 7}: \because g d h A-\mathrm{T}_{\mathrm{T} 7}$ & $\mathrm{p} 15 \mathrm{~A} / \mathrm{Cm}^{\mathrm{R}}$ & This study \\
\hline pGB102 & 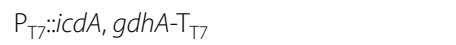 & $\mathrm{p} 15 \mathrm{~A} / \mathrm{Cm}^{\mathrm{R}}$ & This study \\
\hline pGB103 & 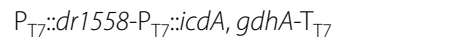 & $\mathrm{p} 15 \mathrm{~A} / \mathrm{Cm}^{\mathrm{R}}$ & This study \\
\hline pREDET & 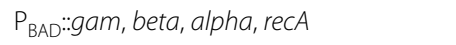 & pSC101/Amp ${ }^{R}$ & Gene Bridges \\
\hline pMloxC & lox66-Cm-lox71 cassette & Co1E1/Amp ${ }^{R}, \mathrm{Cm}^{\mathrm{R}}$ & {$[54]$} \\
\hline pJW168 & Cre-recombinase & pSC101/Amp ${ }^{R}$ & [55] \\
\hline \multicolumn{4}{|l|}{ Strain } \\
\hline BL21(DE3) & fhuA2 [lon] ompT gal ( $\lambda$ DE3) $[\mathrm{dcm}] \Delta h s d S$ & & NEB \\
\hline GB200 & $\mathrm{BL} 21(\mathrm{DE} 3) \Delta g a b T$ & & This study \\
\hline GB300 & $\mathrm{BL} 21(\mathrm{DE} 3) \triangle g a b T, \triangle s u c A$ & & This study \\
\hline WGB100 & $\mathrm{BL} 21(\mathrm{DE} 3) / \mathrm{pGB} 100, \mathrm{pH} 3 \mathrm{BN}$ & & This study \\
\hline WGB200 & GB200/pGB100, pH3BN & & This study \\
\hline DGB101 & $\mathrm{BL} 21(\mathrm{DE} 3) / \mathrm{pGB101}, \mathrm{pH} 3 \mathrm{BN}$ & & This study \\
\hline DGB102 & $\mathrm{BL} 21(\mathrm{DE} 3) / \mathrm{pGB} 102, \mathrm{pH} 3 \mathrm{BN}$ & & This study \\
\hline DGB201 & GB200/pGB101, pH3BN & & This study \\
\hline DGB202 & GB200/pGB102, pH3BN & & This study \\
\hline DGB203 & GB200/pGB103, pH3BN & & This study \\
\hline DGB301 & GB300/pGB101, pH3BN & & This study \\
\hline DGB302 & GB300/pGB102, pH3BN & & This study \\
\hline DGB303 & GB300/pGB103, pH3BN & & This study \\
\hline
\end{tabular}

resulted in decreasing the $\mathrm{pH}$ in the culture medium, GABA was produced from glucose by the E. coli DGB201 and DGB202 strains (Additional file 1: Figure S1). However, the E. coli DGB201 and DGB202 strains exhibited a low production of GABA (up to 0.19 and $0.4 \mathrm{~g} / \mathrm{L}$, respectively) from $30 \mathrm{~g} / \mathrm{L}$ of glucose when they were cultured in the medium without additional inorganic nitrogen source at an initial pH of 7.0 (Fig. 3c). To produce GABA from glucose efficiently, the production of glutamate should be properly supported by the recombinant $E$. coli host strain. Previous studies have reported that the supplementation of inorganic nitrogen sources, such as
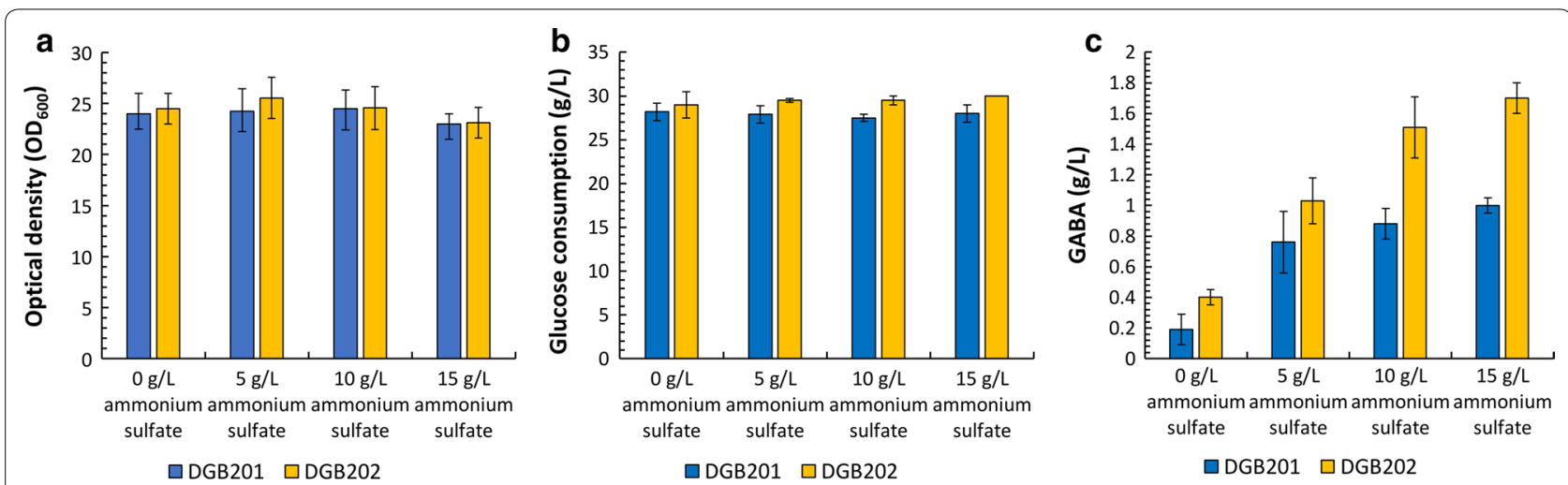

Fig. 3 Effect of ammonium sulfate supplementation on cell growth, glucose consumption, and gamma aminobutyric acid (GABA) production. The Escherichia coli DGB201 and DGB202 strains were cultured in MR medium supplemented with $30 \mathrm{~g} / \mathrm{L}$ glucose, $5 \mathrm{~g} / \mathrm{L}$ yeast extract, and $(0,5,10$, or $15 \mathrm{~g} / \mathrm{L}$ ) ammonium sulfate. a Cell growth; $\mathbf{b}$ glucose consumption; c GABA production. Histogram shows the mean of three biological replicates and error bars represent standard deviation 
ammonium sulfate, urea, and ammonium chloride in the culture medium improved the production of $\mathrm{L}$-amino acid by the microbial host strain [53]. Hence, ammonium sulfate was added to the culture medium containing $30 \mathrm{~g} / \mathrm{L}$ glucose to examine its effect on the production of GABA. The cell growth and glucose consumption in both the E. coli DGB201 and DGB202 strains were not markedly affected with supplementation of ammonium sulfate at concentrations of up to $15 \mathrm{~g} / \mathrm{L}$ (Fig. 3a, b). Interestingly, glutamate was not detected in any of the culture media and GABA production was proportional to the concentration of ammonium sulfate in the culture medium. The supplementation of $15 \mathrm{~g} / \mathrm{L}$ ammonium sulfate resulted in the highest GABA concentrations of 1.7 and $1 \mathrm{~g} / \mathrm{L}$ in the E. coli DGB202 and E. coli DGB201 strain, respectively (Fig. 3c).

\section{Effect of DR1558 on direct production of GABA from recombinant $E$. coli}

The effect of DR1558 on the production of GABA was examined in the E. coli DGB203 (BL21(DE3) $\Delta g a b T$ expressing IcdA, GdhA, GadBC, and DR1558) strain. The $E$. coli DGB202 (BL21(DE3) $\Delta g a b T$ expressing IcdA, GdhA, and GadBC) strain was used as a control. Both $E$. coli strains were cultured in the MR medium supplemented with $30 \mathrm{~g} / \mathrm{L}$ glucose, $5 \mathrm{~g} / \mathrm{L}$ yeast extract, and $15 \mathrm{~g} / \mathrm{L}$ ammonium sulfate at an initial $\mathrm{pH}$ of 7.0 for $24 \mathrm{~h}$. When the cultures reached an $\mathrm{OD}_{600}$ of $0.5,0.5 \mathrm{mM}$ IPTG was added to induce the GABA production pathway.

The E. coli DGB203 strain exhibited a higher glucose consumption than the E. coli DGB202 strain (Fig. 4b). The final cell density of the E. coli DGB202 strain was higher than that of the E. coli DGB203 strain (Fig. 4a). Although glutamate was not detected in both $E$. coli DGB202 and DGB203 strains during cultivation, the titer and yield of GABA production in the E. coli DGB203 strain increased from 1.6 to $2.8 \mathrm{~g} / \mathrm{L}$ and 0.059 to 0.093 $\left(\mathrm{g}_{\mathrm{GABA}} / \mathrm{g}_{\mathrm{Glucose}}\right)$, respectively, when compared to those in the E. coli DGB202 strain (Fig. 4c, d).

As the yields of GABA obtained in both $E$. coli DGB202 and DGB203 strains were low, sucA encoding 2-oxoglutarate decarboxylase, which competes with $g d h A$ encoding glutamate dehydrogenase in the GABA pathway, was deleted in the E. coli GB200 (BL21(DE3) $\Delta g a b T$ ) strain. The GABA titer in the $E$. coli DGB303 (BL21(DE3) $\Delta g a b T$ $\triangle$ sucA expressing IcdA, GdhA, GadBC, and DR1558) strain slightly increased from 2.82 to $3.08 \mathrm{~g} / \mathrm{L}$ when compared to that in the E. coli DGB203 strain. Additionally, the yield of GABA in the E. coli DGB303 strain significantly increased from 0.093 to $0.41\left(\mathrm{~g}_{\mathrm{GABA}} / \mathrm{g}_{\mathrm{Glucose}}\right)$, corresponding to a 4.41-fold increase, when compared to that in the E. coli DGB203 strain (Fig. 4d). However, the productivity of GABA production in the E. coli DGB303 strain decreased from 0.12 to $0.064(\mathrm{~g} / \mathrm{L} / \mathrm{h})$ when compared to that in the E. coli DGB203 strain. As sucA is an essential gene for $E$. coli cell growth, the final cell density of $E$. coli DGB303 was lower than that of $E$. coli DGB203. Therefore, E. coli DGB203 strain was selected for further experiments.

Interestingly, the E. coli DGB302 (BL21(DE3) $\Delta g a b T$ $\triangle s u c A$ expressing IcdA, GdhA, and GadBC genes) strain failed to convert glutamate into GABA and secreted $1.13 \mathrm{~g} / \mathrm{L}$ glutamate into the culture medium, whereas the E. coli DGB303 strain did not secrete glutamate into the culture medium (Fig. 4c, d).

\section{Production of GABA from glucose in fed-batch culture}

To optimize the concentration of IPTG in the culture medium, different concentrations of IPTG $(0.05,0.1,0.5$, or $1 \mathrm{mM}$ ) were supplemented in the MR medium with a glucose/ammonium sulfate ratio of 2 . The cell growth in the medium supplemented with 0.05 and $0.1 \mathrm{mM}$ IPTG significantly decreased (from 23 to 16 of $\mathrm{OD}_{600}$ ) when compared to that in the medium supplemented with $0.5 \mathrm{mM}$ IPTG. However, in all concentrations of IPTG except for $1 \mathrm{mM}$, the titer of GABA was increased by the addition of IPTG. The highest titer of GABA $(2.79 \mathrm{~g} / \mathrm{L})$ was obtained in the medium supplemented with $0.5 \mathrm{mM}$ IPTG (Fig. 5). Based on these results, the fed-batch culture of the E. coli DGB203 strain was performed in the MR medium with a glucose/ammonium sulfate ratio of 2 and 0.5 mM IPTG.

The cells were cultured till $\mathrm{OD}_{600}$ of 5 at $\mathrm{pH} 7.0$ and IPTG was added to the culture medium at a final concentration of $0.5 \mathrm{mM}$ to induce protein expression. The cells were further cultured for $5 \mathrm{~h}$ at $\mathrm{pH} 7.0$ and then the $\mathrm{pH}$ was lowered to 5.0. GABA was initially not detected in the culture medium at $\mathrm{pH} 7.0$ after induction. However, decreasing the $\mathrm{pH}$ to 5.0 and the addition of glucose enhanced the GABA production. The cell density reached an $\mathrm{OD}_{600}$ of 82 in $38 \mathrm{~h}$. The titer of GABA reached $6.16 \mathrm{~g} / \mathrm{L}$ after $38 \mathrm{~h}$ and the glucose consumption was $116.82 \mathrm{~g} / \mathrm{L}$. During fed-batch fermentation, glutamate and fermentative by-products, such as acetate and lactate were not detected in the culture medium (Fig. 6). These results indicated that DR1558 was beneficial for the carbon flux toward GABA production under acidic environmental conditions at the fermentation scale.

Currently, there are several reports on direct fermentative production of GABA from glucose using engineered $E$. coli. The recombinant $E$. coli containing the synthetic scaffolds between $i c d A, \operatorname{glt} B$, and $\operatorname{gadB}$ produced $1.3 \mathrm{~g} / \mathrm{L}$ of GABA from $10 \mathrm{~g} / \mathrm{L}$ glucose in $48 \mathrm{~h}$ [25]. Additionally, GABA production from glucose through GABA shunt in the recombinant $E$. coli was $1.08 \mathrm{~g} / \mathrm{L}$ from $10 \mathrm{~g} / \mathrm{L}$ glucose in $48 \mathrm{~h}$ [30]. Recently, synthetic metabolic toggle 

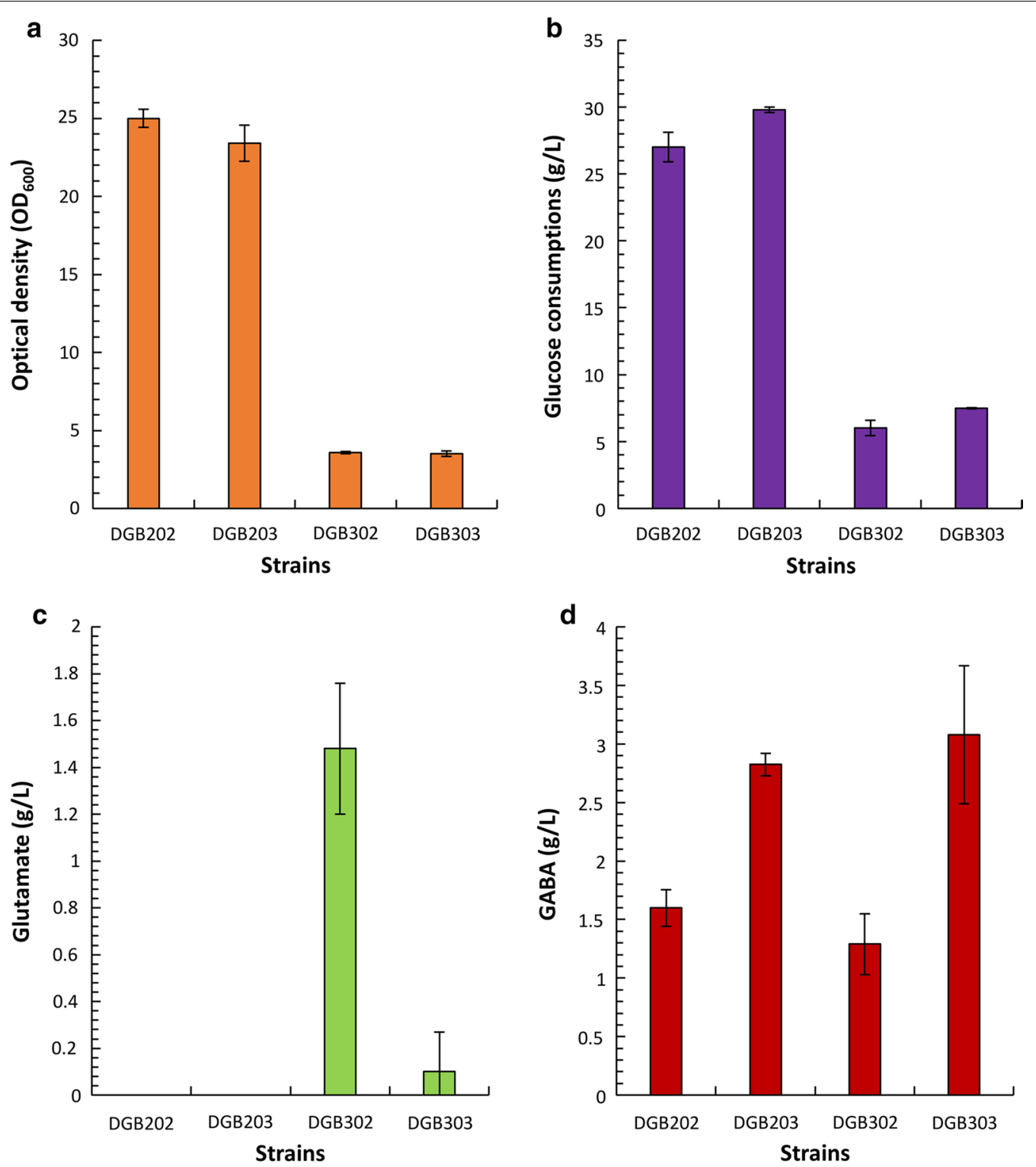

Fig. 4 Effect of DR1558 on cell growth, glucose consumption, glutamate production, and gamma aminobutyric acid (GABA) production in the recombinant Escherichia coli. The E. coli DGB202 and DGB203 strains were cultured in MR medium supplemented with $5 \mathrm{~g} / \mathrm{L}$ yeast extract, $30 \mathrm{~g} / \mathrm{L}$ glucose, and $15 \mathrm{~g} / \mathrm{L}$ ammonium sulfate for $24 \mathrm{~h}$. The E. coli DGB302 and DGB303 strains were cultured in MR medium supplemented with $5 \mathrm{~g} / \mathrm{L}$ yeast extract, $20 \mathrm{~g} / \mathrm{L}$ glucose, and $10 \mathrm{~g} / \mathrm{L}$ ammonium sulfate for $48 \mathrm{~h}$. a Cell growth; $\mathbf{b}$ glucose consumption; c glutamate production; $\mathbf{d}$ GABA production. Histogram shows the mean of three biological replicates and error bars represent standard deviation

switch, which controls the expression of multiple metabolic states, was introduced in E. coli to produce GABA from glucose, which resulted in the production of $4.8 \mathrm{~g} / \mathrm{L}$ GABA from $20 \mathrm{~g} / \mathrm{L}$ glucose [56]. However, these GABA fermentation processes were performed in the shake flask scale. In this study, we demonstrated that introducing DR1558 in the GABA-producing E. coli provides robustness to cells against acid stress for fermentative scale production of GABA from glucose under acid culture conditions. Thus, this study provides an engineering strategy for GABA production from glucose in industrial processes under low $\mathrm{pH}$ condition.

\section{Conclusions}

In this study, we reported that DR1558 can enhance the production of GABA at low $\mathrm{pH}$, optimal for GAD which had been a limiting factor for fermentative GABA production in the recombinant $E$. coli. We developed two 


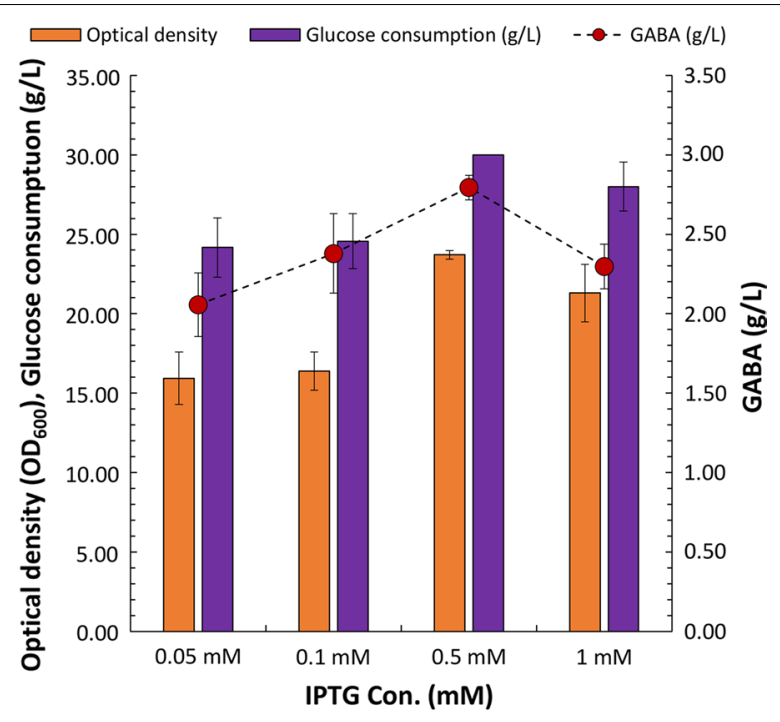

Fig. 5 Effect of isopropyl- $\beta$-thiogalactoside (IPTG) on cell growth, glucose consumption, and gamma aminobutyric acid (GABA) production. The Escherichia coli DGB203 strain was cultured in MR medium supplemented with $5 \mathrm{~g} / \mathrm{L}$ yeast extract, $30 \mathrm{~g} / \mathrm{L}$ glucose, and $15 \mathrm{~g} / \mathrm{L}$ ammonium sulfate for $24 \mathrm{~h}$. Histogram shows the mean of three biological replicates and error bars represent standard deviation

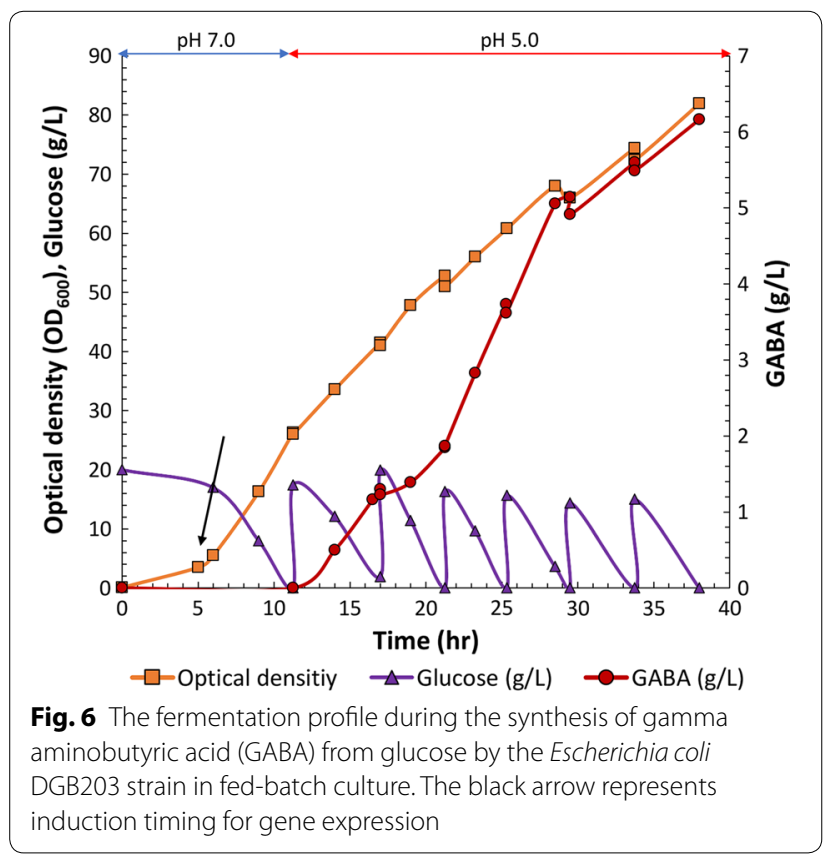

different GABA production strategies: whole-cell bioconversion of GABA from MSG and direct fermentative production of GABA from glucose. Under low $\mathrm{pH}$ culture conditions, the dr1558-overexpressing E. coli exhibited enhanced cell growth rate and GABA production. Furthermore, the transcriptional analysis revealed that DR1558 enabled the growth of $E$. coli at $\mathrm{pH} 4.5$ by increasing the expression levels of GDAR system and proton-pumping respiratory chain complexes. As the bioconversion of GABA from glutamate was observed with optimal cell viability under acidic conditions by the introduction of DR1558, fermentative production of GABA from glucose was also examined. The fermentative process enhanced the production of GABA with the expression of $d r 1558$ in E. coli (Fig. 7). To the best of our knowledge, this is the first study to report the acidic fermentation of GABA. This study provides an engineering strategy for conferring AR to E. coli, which can be used to produce GABA via the GAD system that functions at low $\mathrm{pH}$.

\section{Methods}

\section{Bacterial strains and plasmids}

All bacterial strains, plasmids, and primers used in this study are listed in Table 1 and Additional file 1: Table S1. In this study, E. coli XL1-Blue (Stratagene Cloning Systems, La Jolla, CA, USA) was used for standard gene cloning. For the synthesis of GABA, E. coli BL21 (DE3) (New England Biolabs, Ipswich, MA, USA) and its mutants were used as host strains.

The E. coli GB200 (BL21(DE3) $\Delta g a b T$ ) and GB300 (BL21(DE3) $\triangle g a b T \Delta s u c A$ ) strains were constructed by deleting the corresponding genes in the chromosome of E. coli BL21(DE3) using the single-step gene knockout method as previously described [57].

The construction of $\mathrm{pH} 3 \mathrm{BN}$ plasmid expressing $N$. crassa $\operatorname{gadB}$ and $E$. coli gadC, which convert glutamate into GABA, was previously described [41]. The pGB100 plasmid was constructed by inserting the $d r 1558$ gene, which was amplified by PCR using the dr1558-F and dr1558-R primers, from the genomic DNA of $D$. radiodurans into the pACYCDuet-1 (Novagen, Madison, WI, USA) plasmid at the NcoI and BamHI restriction sites.

The pGB101, pGB102, and pGB103 plasmids were constructed based on the pACYCDuet-1 plasmid to synthesize endogenous glutamate, a precursor of GABA, from glucose. The pGB101 plasmid was constructed by inserting the $E$. coli gdhA gene into the pACYCDuet-1 plasmid at the EcoRV and $X h o I$ restriction sites. The pGB102 plasmid was constructed by inserting the $E$. coli icdA gene into the pGB101 plasmid at the NdeI and BglII restriction sites. Finally, the $d r 1558$ gene was inserted into the pGB102 plasmid at the NcoI and BamHI restriction sites to generate the pGB103 plasmid.

\section{Culture condition for whole-cell bioconversion of glutamate to GABA}

The E. coli WGB100 strain was used as a host strain for whole-cell bioconversion of glutamate to GABA. The 


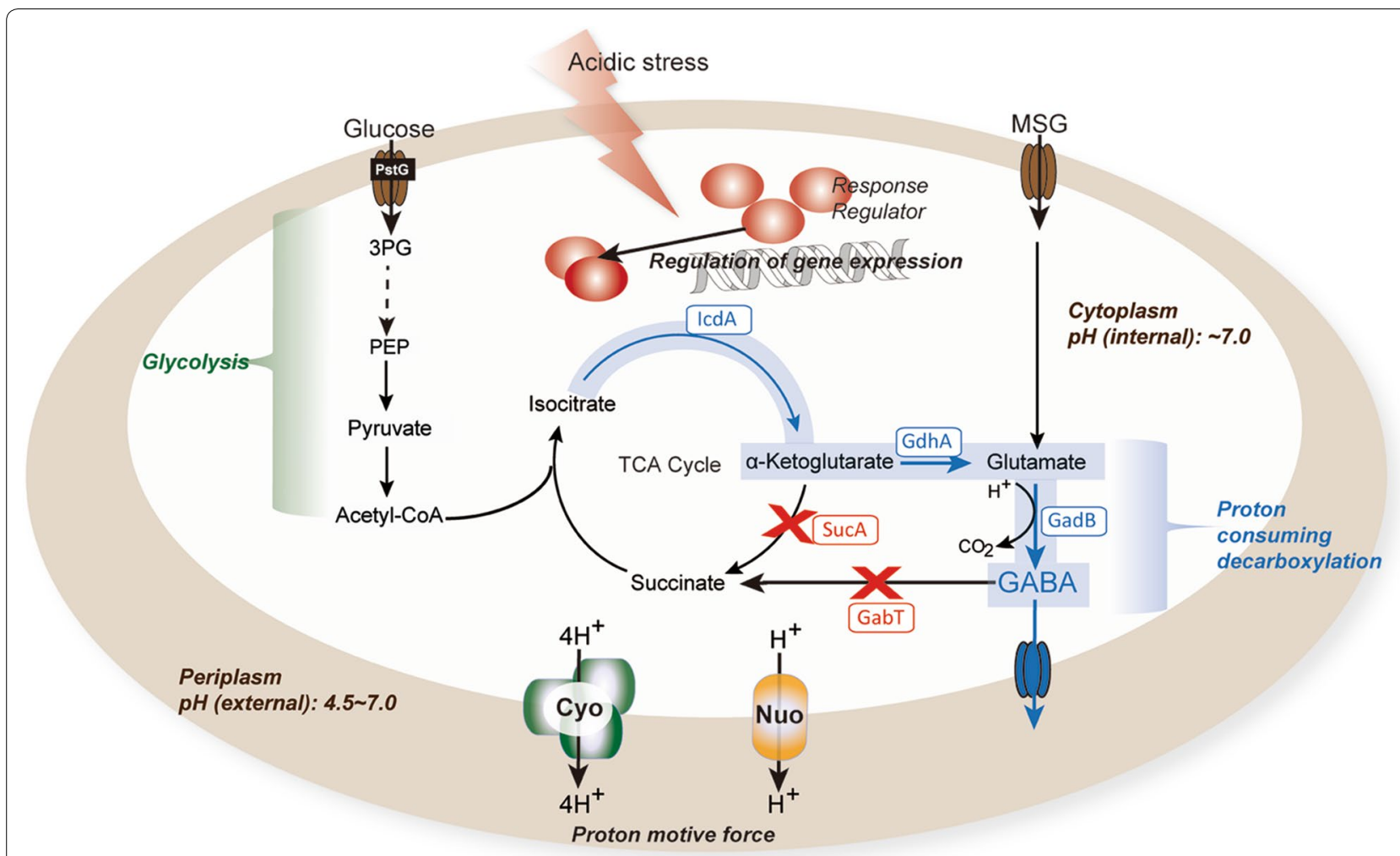

Fig. 7 Metabolic engineering of E. coli for the production of gamma aminobutyric acid (GABA) using a response regulator. The blue line represents gene overexpression. The red X's represents knockout of genes

seed cultures were cultivated at $30{ }^{\circ} \mathrm{C}$ in a $10-\mathrm{mL}$ tube containing $3 \mathrm{~mL}$ Luria-Bertani (LB) medium $(10 \mathrm{~g} / \mathrm{L}$ tryptone, $5 \mathrm{~g} / \mathrm{L}$ yeast extract, and $5 \mathrm{~g} / \mathrm{L} \mathrm{NaCl})$ for $12 \mathrm{~h}$ at $250 \mathrm{rpm}$. For shake flask cultures, $3 \%(\mathrm{v} / \mathrm{v})$ seed cultures were added to $50 \mathrm{~mL}$ MR medium supplemented with $20 \mathrm{~g} / \mathrm{L}$ glucose and $5 \mathrm{~g} / \mathrm{L}$ yeast extract. The composition of the MR medium (pH 7.0) was as follows: $6.67 \mathrm{~g} / \mathrm{L}$ $\mathrm{KH}_{2} \mathrm{PO}_{4}, 4 \mathrm{~g} / \mathrm{L}\left(\mathrm{NH}_{4}\right)_{2} \mathrm{HPO}_{4}, 0.8 \mathrm{~g} / \mathrm{L} \quad \mathrm{MgSO}_{4} \cdot 7 \mathrm{H}_{2} \mathrm{O}$, $0.8 \mathrm{~g} / \mathrm{L}$ citric acid, and $5 \mathrm{~mL} / \mathrm{L}$ of trace metal solution. The composition of trace metal solution was as follows: $10 \mathrm{~g} / \mathrm{L} \mathrm{FeSO} \mathrm{F}_{4} \cdot 7 \mathrm{H}_{2} \mathrm{O}, 2 \mathrm{~g} / \mathrm{L} \mathrm{CaCl} 2,2.2 \mathrm{~g} / \mathrm{L} \mathrm{ZnSO}_{4} \cdot 7 \mathrm{H}_{2} \mathrm{O}$, $0.5 \mathrm{~g} / \mathrm{L} \quad \mathrm{MnSO}_{4} \cdot 4 \mathrm{H}_{2} \mathrm{O}, 1 \mathrm{~g} / \mathrm{L} \quad \mathrm{CuSO}_{4} \cdot 5 \mathrm{H}_{2} \mathrm{O}, 0.1 \mathrm{~g} / \mathrm{L}$ $\left(\mathrm{NH}_{4}\right)_{6} \mathrm{Mo}_{7} \mathrm{O}_{24} \cdot 4 \mathrm{H}_{2} \mathrm{O}$, and $0.02 \mathrm{~g} / \mathrm{L} \mathrm{Na}_{2} \mathrm{~B}_{4} \mathrm{O}_{7} \cdot 10 \mathrm{H}_{2} \mathrm{O}$ prepared in $0.5 \mathrm{M} \mathrm{HCl}$. $\mathrm{MgSO}_{4} \cdot 7 \mathrm{H}_{2} \mathrm{O}$ was sterilized separately. Ampicillin (Ap, $100 \mu \mathrm{g} / \mathrm{mL}$ ) and chloramphenicol $(\mathrm{Cm}, 35 \mu \mathrm{g} / \mathrm{mL})$ were added to the medium depending on the antibiotic resistance marker of plasmids. When the $\mathrm{OD}_{600}$ of the culture reached 1.0, IPTG was added to the culture medium at a final concentration of $0.5 \mathrm{mM}$ to induce protein expression. The cells were cultured for $8 \mathrm{~h}$ after IPTG induction. The recombinant $E$. coli strain was harvested by centrifugation at $8000 \mathrm{~g}$ and $4{ }^{\circ} \mathrm{C}$ for $10 \mathrm{~min}$. The cell pellet was washed with distilled water to remove the salts. The cells were then transferred to fresh MR $(\mathrm{pH}$
4.5) medium supplemented with $20 \mathrm{~g} / \mathrm{L}$ glucose, $5 \mathrm{~g} / \mathrm{L}$ yeast extract, and $13 \mathrm{~g} / \mathrm{L}$ MSG $\cdot \mathrm{H}_{2} \mathrm{O}$ (Dae Jung Chemicals and Metals Co. Ltd., Siheung, Korea) for the production of GABA.

\section{Culture condition for direct synthesis of GABA from glucose}

For the direct synthesis of GABA from glucose, the recombinant E. coli DGB201, DGB202, and DGB203 strains were cultured in MR medium ( $\mathrm{pH}$ 7.0) supplemented with $30 \mathrm{~g} / \mathrm{L}$ glucose, $5 \mathrm{~g} / \mathrm{L}$ yeast extract, and $15 \mathrm{~g} / \mathrm{L}$ ammonium sulfate at $30^{\circ} \mathrm{C}$ for $24 \mathrm{~h}$. The recombinant $E$. coli DGB302 and DGB303 strains were cultured in the MR medium ( $\mathrm{pH}$ 7.0) supplemented with $20 \mathrm{~g} / \mathrm{L}$ glucose, $5 \mathrm{~g} / \mathrm{L}$ yeast extract, and $10 \mathrm{~g} / \mathrm{L}$ ammonium sulfate at $30{ }^{\circ} \mathrm{C}$ for $48 \mathrm{~h}$. Next, $35 \mu \mathrm{g} / \mathrm{mL}$ chloramphenicol and $100 \mu \mathrm{g} / \mathrm{mL}$ ampicillin were added to the culture medium. When the $\mathrm{OD}_{600}$ of the culture reached 0.5 , IPTG was added to the culture medium at a final concentration of $0.5 \mathrm{mM}$.

The fed-batch culture was performed at $30{ }^{\circ} \mathrm{C}$ in a 5 -L bioreactor (BioCNS, Daejeon, Korea) containing $1.8 \mathrm{~L}$ of MR medium supplemented with $5 \mathrm{~g} / \mathrm{L}$ yeast extract, $20 \mathrm{~g} / \mathrm{L}$ glucose, and $10 \mathrm{~g} / \mathrm{L}$ ammonium sulfate. The seed 
culture $(200 \mathrm{~mL})$ was prepared in LB medium. When the $\mathrm{OD}_{600}$ of the culture reached 5, IPTG was added to the culture medium at a final concentration of $0.5 \mathrm{mM}$ for inducing protein expression. The culture $\mathrm{pH}$ was adjusted using $5 \mathrm{M} \mathrm{NaOH}$ and $5 \mathrm{M} \mathrm{HCl}$. The level of dissolved oxygen concentration (DOC) was maintained at $20 \%$ by automatically increasing the agitation speed to $1000 \mathrm{rpm}$ and supplying pure oxygen. The feeding nutrition solutions were added to the culture medium when glucose levels depleted. The composition of the feeding nutrition was as follows: $500 \mathrm{~g} / \mathrm{L}$ glucose, $500 \mathrm{~g} / \mathrm{L}$ ammonium sulfate, $400 \mathrm{~g} / \mathrm{L}$ yeast extract, $150 \mathrm{~g} / \mathrm{L} \mathrm{MgSO}_{4} \cdot 7 \mathrm{H}_{2} \mathrm{O}$. For the GABA production, the culture $\mathrm{pH}$ was adjusted to 5.0 using $5 \mathrm{M} \mathrm{HCl}$ when the initially supplied glucose levels depleted.

\section{Analytical procedure}

The cell growth was analyzed by measuring the optical density $\left(\mathrm{OD}_{600}\right)$ using a UV spectrophotometer (Molecular Devices, San Jose, CA). To determine the GABA and glutamate contents, the cell supernatants were analyzed by high-performance liquid chromatography (HPLC, Agilent Technologies Inc., Santa Clara, CA) equipped with ZORBAX SB-C18 column $(250 \times 4.6 \mathrm{~mm})$ (Agilent Technologies Inc., Santa Clara, CA) as described previously [58]. The concentrations of organic acids and glucose were analyzed by HPLC equipped with Aminex HPX-76H column $(300 \times 7.8 \mathrm{~mm})$ (Bio-Rad, Hercules, CA).

\section{qRT-PCR}

To investigate the changes in the gene expression pattern, the cells were cultured for $3 \mathrm{~h}$ after the $\mathrm{pH}$ was reduced to 4.5 . The cells were then harvested by centrifugation at $10,000 \mathrm{~g}$ and $4{ }^{\circ} \mathrm{C}$ for $5 \mathrm{~min}$ (Fig. 1). Total RNA was extracted using the RNA mini prep kit (Qiagen, Venlo, The Netherlands), following the manufacturer's instructions. The isolated RNA was reverse transcribed using the first-strand cDNA synthesis kit (TaKaRa Bio Inc., Kusatsu, Japan), following the manufacturer's instructions. The primers used in the qRT-PCR analysis are described in Additional file 1: Table S1. To analyze the transcriptional level, $20 \mathrm{ng}$ of template cDNA and 10 pmol of each primer were added to the TB green premix Ex Taq (TaKaRa) in a Real-Time PCR system (Illumina Inc., San Diego, CA). The PCR conditions were as follows: 40 cycles of $95{ }^{\circ} \mathrm{C}$ for $10 \mathrm{~s}$ and at $58{ }^{\circ} \mathrm{C}$ for $30 \mathrm{~s}$. The data were $\log _{2}$-transformed and normalized using $2^{-\Delta \Delta \mathrm{Ct}}$ method for the analysis of the relative changes in gene expression. When using the $2^{-\Delta \Delta \mathrm{Ct}}$ method, the transcriptional results are presented as the fold changes in gene expression normalized to the internal control and relative to the untreated control [59]. The internal controls, used in qRT-PCR for the purpose of normalizing the PCRs, were polA and $d n a A$, which encode DNA polymerase I and dual-transcriptional regulator, respectively. Transcriptional analysis of $E$. coli WGB100 (pGB100 and pH3BN) as $d r 1558$ overexpressing strain and E. coli (pH3BN) as control strain was carried out to elucidate how DR1558 affects the metabolic pathway of host cell in GABA production. All experiments were performed in triplicates. The statistical significance of the observed differences in gene expression was evaluated by a student's $t$-test. Genes whose expression differed more than twofold were considered differentially expressed. Only changes with a threshold $P$-value of $<0.05$ were seen as statistically significant.

\section{Supplementary information}

Supplementary information accompanies this paper at https://doi. org/10.1186/s12934-020-01322-3.

Additional file 1: Table S1. Primers used in this study. Table S2. Relative gene expression of $d r 1558$ overexpression strain. Figure S1. Time profile of GABA and $\mathrm{pH}$ in flask cultivation of recombinant E. coli. A) E. coli DGB201 strain expressing GdhA and GadBC genes.; B) E. coli DGB202 strain expressing IcdA, GdhA, and GadBC genes. Strains were cultivated in $50 \mathrm{~mL}$ MR medium supplied with $5 \mathrm{~g} / \mathrm{L}$ Yeast Extract, $30 \mathrm{~g} / \mathrm{L}$ glucose in a baffled flask at $30^{\circ} \mathrm{C}$ for $24 \mathrm{~h}$

\section{Abbreviations}

aceA (ICI): Isocitrate lyase; aceB (MS): Malate synthase; aceE (AceE): Pyruvate dehydrogenase E1 component; ackA (AckA): Acetate kinase; ACOA: AcetylCoA; acs (Acs): Acetyl-CoA synthetase; actP (ActP): Acetate permease; crp (Crp): CAMP receptor protein; $C y O A B C D$ (CyoABCD): Cytochrome $b_{0}$ ubiquinol oxidase; fruR (FruR): Catabolite repressor; G6P: Glucose 6-phosphate; gadA (GadA): Glutamate decarboxylase A; gadB (GadB): Glutamate decarboxylase B; gadC (GadC): Glutamate/gamma-aminobutyrate antiporter; gadE (GadE): DNAbinding transcriptional activator; gadW (GadW): DNA-binding transcriptional dual regulator; gadX (GadX): DNA-binding transcriptional dual regulator; icdA (IcdA): Isocitrate dehydrogenase; ihfA (IHF a subunit): Subunit of integration host factor; mdh (Mdh): Malate dehydrogenase; nuoMN (NuoMN): Subunit of NADH:quinone oxidoreductase I; OAA: Oxaloacetate; $p d h R$ (PdhR): Pyruvate dehydrogenase complex repressor; PEP: Phosphoenolpyruvate; poxB (PoxB): Pyruvate oxidase; pta (Pta): Phosphotransacetylase; ptsG (PtsG): Subunit of enzyme Ilglc; pykA, pykF (Pyk): Pyruvate kinase; PYR: Pyruvate; rpoD (RpoD): RNA polymerase sigma 70 subunit; rpoS (RpoS): RNA polymerase sigma 38 subunit; sdhC (Sdh): Succinate dehydrogenase; sucA (SuCA): 2-oxoglutarate dehydrogenase E1 component; ybaS (YbaS): Glutaminase A; zwf (Zwf): Glucose 6-phosphate dehydrogenase; a-KG: Alpha ketoglutarate.

\section{Acknowledgements}

This work was supported by the National Research Foundation of Korea (NRF) grant funded by the Ministry of Science and ICT (MSIT) (MSIT) (NRF2018R1D1A1B07049359), the C1 Gas Refinery Program through the NRF funded by the MSIT (NRF-2018 M3D3A1A01017988), and a Golden Seed Project Grant funded by Ministry of Oceans and Fisheries (213008-05-3-SB910).

\section{Authors' contributions}

SJP and JC conceived the project. SP, SJP, and JC generated ideas and designed research. SP performed research and analytical experiments. SP and YJS analyzed data. SP, YJS, SJP, and JC wrote the paper. All authors read and approved the final manuscript.

\section{Funding}

Funding sources are declared in acknowledgement section. 


\section{Availability of data and materials}

Please contact corresponding author for data requests.

\section{Ethics approval and consent to participate}

Not applicable. Our manuscript does not report data collected from humans or animals.

\section{Consent for publication}

Not applicable. Our manuscript does not contain any individual person's data in any form.

\section{Competing interests}

The authors declare that they have no competing interests.

Received: 15 November 2019 Accepted: 1 March 2020

Published online: 10 March 2020

\section{References}

1. Kim HT, Baritugo K, Hyun SM, Khang TU, Sohn YJ, Kang KH, Jo SY, Song BK, Park K, Kim IK, Hwang YT, Lee SY, Park SJ, Joo JC. Development of metabolically engineered Corynebacterium glutamicum for enhanced production of cadaverine and its use for the synthesis of bio-polyamide 510. ACS Sus Chem Eng. 2020;8(1):129-38.

2. Oh YH, Eom IY, Joo JC, Yu JH, Song BK, Lee SH, Hong SH, Park SJ. Recent advances in development of biomass pretreatment technologies used in biorefinery for the production of bio-based fuels, chemicals and polymers. Korean J Chem Eng. 2015;32(10):1945-59.

3. Pang B, Valencia LE, Wang J, Wan Y, Lal R, Zargar A, Keasling JD. Technical advances to accelerate modular type I polyketide synthase engineering towards a retro-biosynthetic platform. Biotechnol Bioprocess Eng. 2019;24:413-23.

4. Kim HT, Baritugo K, Oh YH, Hyun SM, Khang TU, Kang KH, Jung SH, Song BK, Park K, Kim IK, Lee MO, Kam Y, Hwang YT, Park SJ, Joo JC. Metabolic engineering of Corynebacterium glutamicum for the high-level production of cadaverine that can be used for the synthesis of bio-polyamide 510. ACS Sustain Chem. 2018;6:5296-305.

5. Kim HT, Kim JK, Cha HG, Kang MJ, Lee HS, Khang TU, Yun EJ, Lee DH, Song BK, Park SJ, Joo JC, Kim KH. Biological valorization of polyethylene terephthalate monomers for waste upcycling. ACS Sustain Chem. 2019;7(24):19396-406.

6. Rhie MN, Kim HT, Jo SY, Chu LL, Baritugo KA, Baylon MG, Lee J, Na JG, Kim LH, Kim TW, Park C, Hong SH, Joo JC, Park SJ. Recent advances in the metabolic engineering of Klebsiella pneumoniae: a potential platform microorganism for biorefineries. Biotehcnol Bioprocess Eng. 2019;24(1):48-64.

7. Do KH, Park HM, Kim SK, Yun HS. Production of cis-vaccenic acid-oriented unsaturated fatty acid in Escherichia coli. Biotechnol Bioprocess Eng. 2018;23(1):100-7.

8. Choi SY, Rhie MN, Kim HT, Joo JC, Cho IJ, Son J, Jo SY, Sohn YJ, Baritugo KA, Pyo J, Lee YJ, Lee SY, Park SJ. Metabolic engineering for the synthesis of polyesters: a 100-year journey from polyhydroxyalkanoates to nonnatural microbial polyesters. Metab Eng. 2020;58:47-81.

9. Sohn YJ, Kim HT, Baritugo KA, Song HM, Ryu MH, Kang KH, Jo SY, Kim H, Kim YJ, Choi J, Park SK, Joo JC, Park SJ. Biosynthesis of polyhydroxyalkanoates from sucrose by metabolically engineered Escherichia coli strains. Int J Biol Macromol. 2020;149:593-9.

10. Shelp BJ, Bown AW, McLean MD. Metabolism and functions of gammaaminobutyric acid. Trends Plant Sci. 1999;4:446-52.

11. Boonstra E, de Kleijn R, Colzato LS, Alkemade A, Forstmann BU, Nieuwenhuis S. Neurotransmitters as food supplements: the effects of GABA on brain and behavior. Front Psychol. 2015;6:1520.

12. Chua J-Y, Koh MKP, Liu S-Q. Gamma-aminobutyric acid: a bioactive compound in foods. Sprouted grains. Amsterdam: Elsevier; 2019. p. 25-54.

13. Kim S-H, Shin B-H, Kim Y-H, Nam S-W, Jeon S-J. Cloning and expression of a full-length glutamate decarboxylase gene from Lactobacillus brevis $\mathrm{BH} 2$. Biotechnol Bioprocess Eng. 2007:12:707-12.

14. Ting Wong CG, Bottiglieri T, Snead OC III. GABA, $Y$-hydroxybutyric acid, and neurological disease. Ann Neurol. 2003;54:S3-12.
15. Park SJ, Kim EY, Noh W, Oh YH, Kim HY, Song BK, Cho KM, Hong SH, Lee $\mathrm{SH}$, Jegal J. Synthesis of nylon 4 from gamma-aminobutyrate (GABA) produced by recombinant Escherichia coli. Bioprocess Biosyst Eng. 2013;36:885-92.

16. Saskiawan I. Biosynthesis of polyamide 4, a biobased and biodegradable polymer. Microbiol Indones. 2008;2:119-23.

17. Le VoTD, Kim TW, Hong SH. Effects of glutamate decarboxylase and gamma-aminobutyric acid (GABA) transporter on the bioconversion of GABA in engineered Escherichia coli. Bioprocess Biosyst Eng. 2012;35:645-50.

18. Le Vo TD, Ko J-s, Lee SH, Park SJ, Hong SH. Overexpression of Neurospora crassa OR74A glutamate decarboxylase in Escherichia coli for efficient GABA production. Biotechnol Bioprocess Eng. 2013;18:1062-6.

19. Le Vo TD, Ko J-s, Lee SH, Park SJ, Hong SH. Improvement of gamma-amino butyric acid production by an overexpression of glutamate decarboxylase from Pyrococcus horikoshii in Escherichia coli. Biotechnol Bioprocess Eng. 2014;19:327-31.

20. Plokhov AY, Gusyatiner M, Yampolskaya T, Kaluzhsky V, Sukhareva B, Schulga A. Preparation of $\gamma$-aminobutyric acid using E. coli cells with high activity of glutamate decarboxylase. Appl Biochem Biotechnol. 2000;88:257-65.

21. Yu P, Chen K, Huang X, Wang X, Ren Q. Production of Y-aminobutyric acid in Escherichia coli by engineering MSG pathway. Prep Biochem Biotechnol. 2018;48:906-13.

22. Yu P, Ren Q, Wang $X$, Huang X. Enhanced biosynthesis of $Y$-aminobutyric acid (GABA) in Escherichia coli by pathway engineering. Biochem Eng J. 2019;141:252-8.

23. Zhao A, Hu X, Li Y, Chen C, Wang X. Extracellular expression of glutamate decarboxylase B in Escherichia coli to improve gamma-aminobutyric acid production. AMB Expr. 2016;6:55.

24. Zhao W-r, Huang J, Peng C-I, Hu S, Ke P-y, Mei L-h, Yao S-j. Permeabilizing Escherichia coli for whole cell biocatalyst with enhanced biotransformation ability from L-glutamate to GABA. J Mol Catal B Enzym. 2014;107:39-46.

25. Pham VD, Lee SH, Park SJ, Hong SH. Production of gamma-aminobutyric acid from glucose by introduction of synthetic scaffolds between isocitrate dehydrogenase, glutamate synthase and glutamate decarboxylase in recombinant Escherichia coli. J Biotechnol. 2015;207:52-7.

26. Okai N, Takahashi C, Hatada K, Ogino C, Kondo A. Disruption of pknG enhances production of gamma-aminobutyric acid by Corynebacterium glutamicum expressing glutamate decarboxylase. AMB Express. 2014;4:20.

27. Shi F, Jiang J, Li Y, Li Y, Xie Y. Enhancement of $Y$-aminobutyric acid production in recombinant Corynebacterium glutamicum by co-expressing two glutamate decarboxylase genes from Lactobacillus brevis. J Ind Microbiol Biotechnol. 2013;40:1285-96.

28. Shi F, Li Y. Synthesis of $\mathrm{Y}$-aminobutyric acid by expressing Lactobacillus brevis-derived glutamate decarboxylase in the Corynebacterium glutamicum strain ATCC 13032. Biotechnol Lett. 2011;33:2469-74.

29. Somasundaram S, Lee SH, Park SJ, Hong SH. Efficient production of gamma-aminobutyric acid using Escherichia coli by co-localization of glutamate synthase, glutamate decarboxylase, and GABA transporter. J Ind Microbiol Biotechnol. 2016:43:79-86.

30. Somasundaram S, Lee SH, Park SJ, Hong SH. Gamma-aminobutyric acid production through GABA shunt by synthetic scaffolds introduction in recombinant Escherichia coli. Biotechnol Bioprocess Eng. 2016;21:261-7.

31. Zhao A, Hu X, Wang X. Metabolic engineering of Escherichia coli to produce gamma-aminobutyric acid using xylose. Appl Microbiol Biotechnol. 2017;101:3587-603.

32. Choi JW, Yim SS, Lee SH, Kang TJ, Park SJ, Jeong KJ. Enhanced production of gamma-aminobutyrate (GABA) in recombinant Corynebacterium glutamicum by expressing glutamate decarboxylase active in expanded pH range. Microb Cell Fact. 2015;14:21.

33. Krisko A, Radman M. Biology of extreme radiation resistance: the way of Deinococcus radiodurans. Cold Spring Harb Perspect Biol. 2013;5:a012765-a012765.

34. Liu Y, Zhou J, Omelchenko MV, Beliaev AS, Venkateswaran A, Stair J, Wu L, Thompson DK, Xu D, Rogozin IB. Transcriptome dynamics of Deinococcus radiodurans recovering from ionizing radiation. Proc Natl Acad Sci USA. 2003;100:4191-6. 
35. Appukuttan D, Singh H, Park S-H, Jung J-H, Jeong S, Seo HS, Choi YJ, Lim S. Engineering synthetic multistress tolerance in Escherichia coli by using a deinococcal response regulator, DR1558. Appl Environ Microbiol. 2016:82:1154-66.

36. Guo S, Yi X, Zhang W, Wu M, Xin F, Dong W, Zhang M, Ma J, Wu H, Jiang $M$. Inducing hyperosmotic stress resistance in succinate-producing Escherichia coli by using the response regulator DR1558 from Deinococcus radiodurans. Process Biochem. 2017;61:30-7.

37. Park S, Sohn YJ, Park SJ, Choi J. Enhanced Production of 2,3-Butanediol in Recombinant Escherichia coli Using Response Regulator DR1558 Derived from Deinococcus radiodurans. Biotehcnol Bioprocess Eng. 2020;25:45-52.

38. Park S-h, Kim GB, Kim HU, Park SJ, Choi J-i. Enhanced production of poly3-hydroxybutyrate (PHB) by expression of response regulator DR1558 in recombinant Escherichia coli. Int J Biol Macromol. 2019;131:29-35.

39. Lawson A, Quinn A. Studies on amino acid decarboxylases in Escherichia coli. Biochem J. 1967;105:483-90.

40. Shukuya R, Schwert GW. Glutamic acid decarboxylase I Isolation procedures and properties of the enzyme. J Biol Chem. 1960;235:1649-52.

41. Somasundaram S, Maruthamuthu MK, Ganesh I, Eom GT, Hong SH. Enchancement of gamma-aminobutyric acid production by co-localization of Neurospora crassa OR74A glutamate decarboxylase with Escherichia coli GABA transporter via synthetic scaffold complex. J Microbiol Biotechnol. 2017;27:1664-9.

42. Foster JW. Escherichia coli acid resistance: tales of an amateur acidophile. Nat Rev Microbiol. 2004;2:898.

43. Kanjee U, Houry WA. Mechanisms of acid resistance in Escherichia coli. Annu Rev Microbiol. 2013;67:65-81.

44. Castanie-Cornet M-P, Penfound TA, Smith D, Elliott JF, Foster JW. Control of acid resistance in Escherichia coli. J Bacteriol. 1999;181:3525-35.

45. lyer R, Williams C, Miller C. Arginine-agmatine antiporter in extreme acid resistance in Escherichia coli. J Bacteriol. 2003;185:6556-61.

46. Kanjee U, Gutsche I, Alexopoulos E, Zhao B, El Bakkouri M, Thibault G, Liu K, Ramachandran S, Snider J, Pai EF. Linkage between the bacterial acid stress and stringent responses: the structure of the inducible lysine decarboxylase. EMBO J. 2011;30:931-44.

47. Kashiwagi K, Suzuki T, Suzuki F, Furuchi T, Kobayashi H, Igarashi K. Coexistence of the genes for putrescine transport protein and ornithine decarboxylase at 16 min on Escherichia coli chromosome. J Biol Chem. 1991;266:20922-7.

48. Feehily C, Karatzas K. Role of glutamate metabolism in bacterial responses towards acid and other stresses. J Appl Microbiol. 2013;114:11-24.
49. Chattopadhyay MK, Keembiyehetty CN, Chen W, Tabor H. Polyamines stimulate the level of the $\sigma 38$ subunit (RpoS) of Escherichia coli RNA polymerase, resulting in the induction of the glutamate decarboxylasedependent acid response system via the gadE regulon. J Biol Chem. 2015;290:17809-21.

50. Seo SW, Kim D, O'Brien EJ, Szubin R, Palsson BO. Decoding genome-wide GadEWX-transcriptional regulatory networks reveals multifaceted cellular responses to acid stress in Escherichia coli. Nat Commun. 2015;6:7970.

51. Krulwich TA, Sachs G, Padan E. Molecular aspects of bacterial pH sensing and homeostasis. Nat Rev Microbiol. 2011;9:330-43.

52. Nishio Y, Ogishima S, Ichikawa M, Yamada Y, Usuda Y, Masuda T, Tanaka H. Analysis of L-glutamic acid fermentation by using a dynamic metabolic simulation model of Escherichia coli. BMC Syst Biol. 2013;7:92.

53. Ginésy M, Rusanova-Naydenova D, Rova U. Tuning of the carbon-to-nitrogen ratio for the production of L-arginine by Escherichia coli. Fermentation (Basel). 2017;3:60.

54. Kim JM, Lee KH, Lee SY. Development of a markerless gene knock-out system for Mannheimia succiniciproducens using a temperature-sensitive plasmid. FEMS Microbiol Lett. 2008; 278:78-85.

55. Palmeros Bz, Wild J, Szybalski W, Le Borgne S, Hernández-Chávez G, Gosset $G$, Valle F, Bolivar F. A family of removable cassettes designed to obtain antibiotic-resistance-free genomic modifications of Escherichia coli and other bacteria. Gene. 2000;247:255-64.

56. Soma Y, Fujiwara Y, Nakagawa T, Tsuruno K, Hanai T. Reconstruction of a metabolic regulatory network in Escherichia coli for purposeful switching from cell growth mode to production mode in direct GABA fermentation from glucose. Metab Eng. 2017;43:54-63.

57. Datsenko KA, Wanner BL. One-step inactivation of chromosomal genes in Escherichia coli K-12 using PCR products. Proc Natl Acad Sci USA. 2000;97:6640-5.

58. Kim YH, Kim HJ, Shin J-H, Bhatia SK, Seo H-M, Kim Y-G, Lee YK, Yang Y-H, Park K. Application of diethyl ethoxymethylenemalonate (DEEMM) derivatization for monitoring of lysine decarboxylase activity. J Mol Catal B Enzym. 2015;115:151-4.

59. Livak KJ, Schmittgen TD. Analysis of relative gene expression data using real-time quantitative PCR and the $2^{-\triangle \Delta C T}$ method. Methods. 2001;25:402-8.

\section{Publisher's Note}

Springer Nature remains neutral with regard to jurisdictional claims in published maps and institutional affiliations.
Ready to submit your research? Choose BMC and benefit from:

- fast, convenient online submission

- thorough peer review by experienced researchers in your field

- rapid publication on acceptance

- support for research data, including large and complex data types

- gold Open Access which fosters wider collaboration and increased citations

- maximum visibility for your research: over 100M website views per year

At BMC, research is always in progress.

Learn more biomedcentral.com/submissions 